10/1894850

CONTRACTOR REPORT

SAND94 - 1057

Unlimited Release

UC $-\frac{1290}{1290}$

\title{
The Interconnection of Photovoltaic Power Systems with the Utility Grid: An Overview for Utility Engineers
}

Dr. Robert H. Wills, P.E.

Principal Electrical Engineer

Solar Design Associates, Inc.

Architects and Engineers

Harvard, MA

Prepared by Sandia National Laboratories Albuquerque, New Mexico 87185

and Livermore, California 94550 for the United States Department of Energy under Contract DE-AC04-94AL85000

Printed June 1994

Approved for public release; distribution is unlimited. 

SAND94-1057

Unlimited Release

Printed June 1994
Distribution

Category

UC1290

\section{The Interconnection of Photovoltaic Power Systems with the Utility Grid : An Overview for Utility Engineers}

Dr. Robert H. Wills, P.E.

Principal Electrical Engineer

Solar Design Associates, Inc.

Architects and Engineers

Harvard, MA

Contract \# AE-5385 


\section{DISCLAIMER}

Portions of this document may be illegible electronic image products. Images are produced from the best available original document. 


\section{Contents}

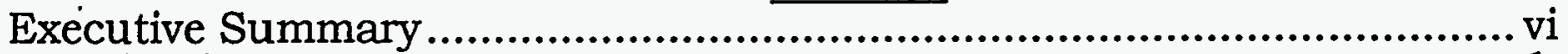

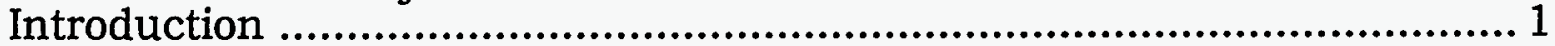

Barriers to Widespread Use................................................................ 2

Barrier 1 - The Price of Photovoltaics ........................................... 2

Barrier 2 - Balance of System Costs............................................. 3

Barrier 3 - Underwriters Laboratories (UL) Listing of Components... 3

Barrier 4 - Interconnection Issues................................................ 3

Barrier 5 - Installation Issues ...................................................... 3

Barrier 6 - Financial Payback ................................................. 3

Specific System Design Issues......................................................... 4

Differences Between Photovoltaic PCUs and Rotating Generators.... 4

System Ownership \& Point of Interconnection ............................... 4

Non-Utility-Specific Issues......................................................... 5

PV Array Mounting and Wiring....................................... 5

DC Voltage and Safety....................................................... 5

Ground Fault Detection and Interruption ............................... 5

Inverter Siting \& Acoustic Noise ..................................... 5

UL Listing of Components ................................................5 5

Grounding of the PV Array Source Circuit ........................... 6

Transient Protection ......................................................... 6

Electromagnetic Interference ......................................... 6

Electromagnetic Fields .........................................................6 6

Utility Specific Issues .............................................................. 6

Interconnection Voltage and Interconnect Location................. 6 Metering Methods \& Financial Arrangements with the Utility 7 Manual Disconnect from the Utility ...................................... 7 Insurance Issues ........................................................ 8

Output Overcurrent Protection ......................................... 8

Power Quality ............................................................. 8

Harmonic Content .............................................. 8

Power Factor .......................................................... 9

DC Injection ................................................... 9

Safety Requirements ....................................................... 10

Protective Relaying .............................................. 10

An Overview of the Design \& Installation Process ................................. 12

1. Preliminary System Design ......................................................... 12

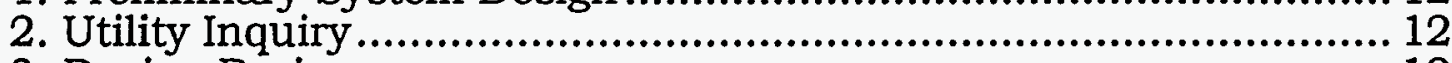

3. Design Review ............................................................ 12

4. Plan check with Utility and Electrical Inspectors....................... 13

5. Procurement \& Transportation .............................................. 13

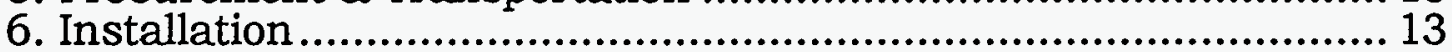

7. Electrical Inspection ......................................................................... 13

8. Utility Pre-Parallel Inspection ................................................. 13

9. System On-Line ................................................................... 13

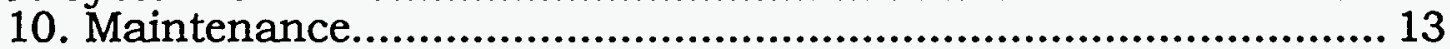

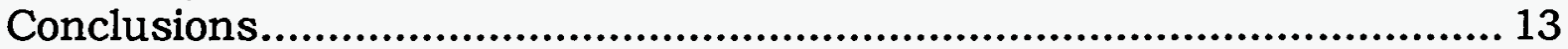




\section{Contents (continued)}

Appendix A - Annotated References................................................... 15

Codes, Standards and Related Documents: .................................. 16

IEEE/ANSI Standards: ............................................................ 17

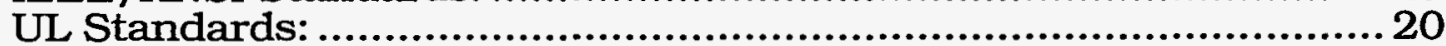

Other Standards:...................................................................... 20

Reports: ........................................................................... 21

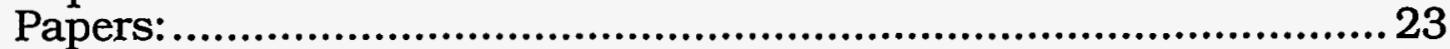

Other References: .................................................................... 24

Appendix B - List of Contact People \& Resources ...................................25 


\section{Executive Summary}

Utility-interactive (UI) photovoltaic power systems mounted on residences and commercial buildings are likely to become a small, but important source of electric generation in the next century. This is a new concept in utility power production-a change from large-scale central generation to small-scale dispersed generation. As such, it requires a re-examination of many existing standards and practices to enable the technology to develop and emerge into the marketplace.

Much work has been done over the last 20 years to identify and solve the potential problems associated with dispersed power generation systems. This report gives an overview of these issues and also provides a guide to applicable codes, standards and other related documents.

The main conclusion that can be drawn from this work is that there are no major technical barriers to the implementation of dispersed PV generating systems. While more technical research is needed in some specific areas, the remaining barriers are fundamentally price and policy.

\section{Technical Barriers Associated with Inverters}

The technical capabilities of utility-interactive inverters with respect to utility interconnection are now quite well understood. For instance standards such as ANSI/IEEE 1035-1989 "IEEE Recommended Practice : Test Procedure for Utility Interconnected Static Power Converters" and reports from the IEEE Power Systems Relaying Committee, Working Group C5 "Static Power Converters of 500 kW or less serving as Relay Interface Package for Non-Conventional Generators" have been established because of the general understanding that there are no fundamental technical barriers to widespread use of these systems.

The only specific technical area that needs clarification is the issue of inverter run-on or islanding. While some instances of run-on have been observed in controlled test conditions with closely matched power production and load, control and monitoring techniques have now developed to the point that islanding should not be a problem if proper control is incorporated in the inverter. For instance, the Sandia report 87-7024 Investigation of Potential Islanding of Dispersed Photovoltaic Systems concludes that "The potential for having an indefinitely long islanding condition for a properly functioning TESLAco [brand of inverter] is nil. The device is designed to be unstable for the loss of utility condition and to shut itself down. All simulations, lab tests and field tests support the fact that a properly functioning TESLAco will not island indefinitely." Unfortunately, the TESLACo unit is no longer commercially avalable, but other manufacturers have developed their own means for avoiding islanding. The extensive islanding testing performed on previous inverters has not yet been performed on today's generation of inverters, but is in the planning stages. While schemes exist to avoid islanding, it is important to ensure that this capability is included in equipment for a specific installation.

\section{Price}

Photovoltaic modules are currently selling for about $\$ 5-\$ 6$ per watt-peak (Wp), while the balance of system and installation costs are typically $\$ 2-\$ 5$ per Wp, 
giving an installed price of $\$ 7$ to $\$ 11$ per Wp. This results in a cost of generated electricity of about 20-40 cents/ $\mathrm{kWh}$ in locations with favorable solar insolation. 1 Clearly, the cost of PV modules and their balance of system must drop to be able to compete with conventional power generation.

The goal of the PV community is, over the long term ( $>15$ years), for PV prices to fall, leading to a time when bulk PV power generation is economically viable.

At the present time, many utility customers are paying a marginal cost of 20 cents per $\mathrm{kWh}$ or more during peak hours, so there is a near-term potential market for peak-shaving distributed PV power systems [e.g. see Shugar, 1991].

In addition, utilities and private parties are investing in distributed PV systems now despite the high cost for reasons involving environmental sensitivity, a desire to gain experience with the technology and public image. For example, the Sacramento Municipal Utility District has recently begun a PV installation effort which they anticipate will result in the installation of some $4.5 \mathrm{MWp}$ of distributed PV systems over the next three years.

\section{Policy}

There are currently four key impediments to the installation of UI photovoltaics:

1/ As this report is written, there is no commercially available PV inverter which has been approved by Underwriters Laboratories (UL). This means that electrical inspectors have no basis on which to accept a PV system with an inverter, as is required for utility interconnection. However, as this is being written, UL is testing two manufacturers' inverters. If these units are approved by UL, it will remove a major impediment to UI photovoltaics.

$2 /$ There is little consistency from utility to utility as to what procedures and technical needs are required for interconnection. Often, small PV power systems (i.e., a few $\mathrm{kW}$ ) have to go through the same process as multimegawatt cogeneration plants, and some utilities require redundant levels of protective relaying, or non-standard trip settings, while others do not.

$3 /$ The cost of installing supplementary revenue metering can often represent many months of energy production.

4/ The value of the solar-electric energy, especially to summer peaking utilities where PV energy is available close to daily peaks, is not always recognized.

To address the last two points, many utilities and state utility commissions in the USA have recognized the benefits of offering net metering rather than avoided cost to small-scale renewable energy producers. There are three reasons for this:

- This is a great incentive for end-users to implement a technology that is just becoming marginally economic.

1Calculated by dividing the PV system cost by the generated kilowatt-hours: ( $1 \mathrm{kWP}^{*} 5$ peak sun hours/day*over a 20-year system life). This assumes no time value of money, the importance of which will vary with the circumstances of individual installations. 
- Because mid-day energy generally has a high value, the utility isn't penalized substantially for (and sometimes profits from) paying retail rates to buy wholesale energy.

- Metering requirements are fewer (needing one, rather than two meters), and accounting is simplified (again because of one meter rather than two) - benefiting both the utility and the end-user.

The following steps will help the transition to the widespread use of distributed photovoltaics:

1/ Encourage UL listing of inverters and other hardware required for UI PV systems. Utilities and inspection agencies can then rely on UL testing to guarantee that equipment will be suitable, and will operate safely.

2/ Develop a set of simplified interconnection guidelines for small-scale systems $(<50 \mathrm{kWp})$ so that interconnection becomes a simple and straightforward process involving minimal filing of paper and engineering time. The availability of UL-listed components and inverters that have been tested in accordance with IEEE 1035 will also simplify the process as the utility could simply state that UL listing and passing IEEE 1035 is adequate proof of acceptable hardware.

3/ Adopt net-metering provisions for small systems to simplify interconnection and metering, and to offer an incentive for the installation of renewable energy systems. 


\section{Introduction}

Photovoltaic power production promises to be a clean, widely applicable renewable energy source available for future energy production. As most of the electric power supply in developed countries is via a centralized electric grid, it is virtually certain that truly widespread use of photovoltaics will be in the form of distributed power generation interconnected with these grids.

This report presents the issues surrounding the interconnection of small-tomedium-scale photovoltaic power systems to utility grids. It is aimed at utility engineers and others interested in utility interconnection.

Although the issues covered in the report apply to residential and commercial systems ranging in size up to $50 \mathrm{~kW}$ peak, many are relevant to larger systems as well.

Individual applications are the main focus of the report, however, many topics are also applicable to multiple systems. Clearly, in the future we may reach levels of penetration where overall power system regulation, stability and predictability become a concern. These issues, however, are beyond the scope of this document.

A key feature of this report is an annotated list of codes, standards and other resources that may aid in understanding and resolving common interconnection problems.

Such distributed systems, which feed solar electricity directly to a utility power grid are called utility interactive (UI) power systems. These systems may be integrated into buildings (both electrically and mechanically), or constructed as independent generating units. Distributed PV systems on buildings are potentially less costly to field than ground-mounted installations due to the availability of "free" real estate and the lower cost of mounting hardware and labor offered by a tilted roof. For this reason, a large number of future installations are likely to be mounted on buildings in which the roof surface and support structure lend themselves to easy installation.

Utility-interactive PV systems consist of an array of photovoltaic modules (which convert solar energy to dc electricity), an inverter (also known as a power conditioning unit or PCU), balance of system (including wiring and mounting structure) and a means of connecting to the electric grid (typically by back-feeding the main electric service distribution panel). The size of the photovoltaic array is rated in terms of its peak output (i.e. in watts peak, or Wp) in bright (i.e., 1 $\mathrm{kW} / \mathrm{m}^{2}$ ) sunlight.

When the sun is shining, direct current (dc) electricity from the photovoltaic modules is converted to ac by the PCU, and fed into the building power distribution system where it supplies building loads. Any excess solar power is exported to the utility power grid, and any shortfall is made up with grid electricity. During non-sun hours, building loads are supplied by utility power alone. 
When compared to stand-alone PV systems, which are not connected to the grid, such utility-interactive (UI) systems have significant advantages:

- Simplicity and lower costs - the system connects to the standard AC wiring and only two components are required - the PV modules (and their associated wiring) and the PCU.

- No Local Storage - as the utility grid provides power during low or non-sun times, no energy storage is required. The utility effectively becomes an energystorage bank, receiving energy when a surplus is generated and delivering energy when the load exceeds on-site generation.

- Utility Benefits - as solar electric production coincides with peak loads in many utility systems, the utility can potentially gain from reduced peak demand and its associated lower generation costs and lower investment in generating and distribution plant (assuming the PV, or a percentage of it, can be counted as firm capacity.) There are also benefits in terms of line support [e.g., see Shugar, 1991], in that heavily loaded transmission and distribution systems may not need upgrading if sufficient PV power is generated at the point of use, and is coincident with the peak load demand.

With utility-interactive PV systems, daytime peaking utilities gain a reduction in peak load while not impacting off-peak energy sales. This is a win-win situation: the customer benefits by having lower utility bills, while the utility is assisted in operating more efficiently.

\section{Barriers to Widespread Use}

To date, there are only about 300 utility-interactive PV systems operating in the USA. Before utility interactive photovoltaic systems can achieve widespread market acceptance, several barriers need to be overcome. These are mainly related to the direct and indirect costs associated with PV system installation, and to cumbersome policies regarding installation and metering. To put these costs into perspective, consider a $4-\mathrm{kWp}$ residential rooftop array that produces on average $16 \mathrm{kWh}$ per day, or $5,800 \mathrm{kWh}$ per year. At a selling price of 8 cents per $\mathrm{kWh}$ the value of the electricity generated by this system will be under $\$ 500$ per year.

\section{Barrier 1 - The Price of Photovoltaics}

At present, utility-interactive photovoltaic systems cost about \$7-11/watt peak (Wp) when installed on a residential roof. Residential roofs are the lowest-cost siting option as both the real-estate and mounting structure are provided at no cost. The system cost includes about $\$ 5-6 / \mathrm{Wp}$ for the photovoltaic modules, $\$ 1 / \mathrm{Wp}$ for power conditioning, and \$1-4 for mounting and labor. A complete installed $4 \mathrm{kWp}$ system will cost about $\$ 28,000$ to $\$ 44,000$. 
In a US solar location, receiving an average of 5 sun-hours/day (for example, Orlando, Atlanta, Omaha, Oklahoma City or Great Falls, Montana) this 4kWp system will produce a little over $7000 \mathrm{kWh} /$ year. At a value of $\$ .10 / \mathrm{kWh}$, this energy is worth a little over $\$ 700 /$ year. Clearly, people who install such systems today are doing so for other than economic reasons. It is anticipated that the cost of PV systems will be reduced to the point that simple economics will be an installation consideration.

\section{Barrier 2 - Balance of System Costs}

As photovoltaic module costs fall, the cost of balance of system (BOS) components--PCU, wiring systems, mounting hardware and installation labor become a far-more significant part of the overall total installed cost. Balance of system costs must be reduced along with module cost to make the PV systems economically viable.

\section{Barrier 3 - Underwriters Laboratories (UL) Listing of Components}

At present, three photovoltaic manufacturers make PV modules that are listed under UL-1703, Flat Plate Photovoltaic Modules and Panels. There are presently no UL-listed or labeled photovoltaic PCUs for utility interconnection commercially available, although two manufacturers currently have units undergoing UL testing.

Lack of UL (or equivalent Nationally Recognized Testing.Lab) listing is becoming an increasing problem as state and local electrical inspectors are tending to require UL or equivalent listing of equipment to better ensure public safety, and to minimize their own liability exposure. The NEC, in Article 110-2, requires that conductors and equipment be "approved:" Such approval is defined as "acceptable to the authority having jurisdiction" and so is generally the responsibility of the electrical inspection authority, which in turn now tends to base approvals on tests and listings of testing laboratories.

UL listing is an expensive and time-consuming process that must be re-visited each time the product is modified. This is a difficult problem for the PCU manufacturer whose equipment is still evolving, and whose total sales volume has been of the order of 100 units per year. However, the UL listing of more PV modules and utility interactive PCUs is a necessary and critical step in gaining the acceptance of UI PV systems by code officials and utilities so essential for their widespread use.

\section{Barrier 4 - Interconnection Issues}

The very process of gaining interconnection approval from a utility can often be a significant cost barrier for photovoltaic systems. At present, interconnection requirements vary from utility to utility, and the need to negotiate interconnection agreements can result in initial engineering costs greater than 5 or even 10 years' power production. There are two main areas of concern--the actual process, and technical requirements.

The interconnection process, wherein the customer and utility enter a legal agreement to respectively produce and buy power, is often unnecessarily complex (the guidelines and forms for 2-kW PV systems needn't be as elaborate as those for 2-MW cogeneration systems.) The engineering costs of reviewing the interconnection guidelines and completing the necessary forms can be very expensive. Simplified guidelines and paperwork, as well as standardized procedures (in those situations where this wouldn't compromise the utility's operation,) would help to encourage installation of PV systems. 
The technical requirements set out by utilities also vary widely. For example, some utilities require additional redundant protective relaying on static power converters, and some impose limits for voltage and frequency relay trips that are more stringent than the existing IEEE standards. This variation is untenable in the long term, as it is just not practical, or cost effective, to manufacture PCUs with custom features for each utility in the country. The existing IEEE standards and proposed UL standards need to be reviewed and accepted by utilities as a universal basis for acceptance of this equipment.

\section{Barrier 5 - Installation Issues}

As this is a very young industry, equipment development is still in its infancy, standards are still being developed, and both installers and code officials lack experience with these systems.

\section{Barrier 6 - Financial Payback}

Ultimately, for photovoltaics to gain widespread use, the overall financial benefit must outweigh the initial capital cost. Ignoring environmental benefits, which are difficult to quantify, the main benefit to the user is payment for electricity generated. The Public Utility Regulatory Policies Act of 1978 (PURPA) mandates that independent power producers be paid at the rate of the utility's avoided cost, but this is often considerably less than the selling rate and so is a strong disincentive for utility interconnection.

At present, six states (Massachusetts, Maine, Oklahoma, Wisconsin, Texas and Minnesota) mandate that small renewable power producers below a certain power limit (typically 30 to $50 \mathrm{~kW}$ ) be paid at the same rate for both buying and selling. This is termed net metering. In addition, Colorado, California and Connecticut are considering implementing the same policy, and some utilities, notably Southern California Edison, have implemented a net-metering rate on their own.

Net metering makes sense for three reasons:

- Because mid-day energy generally has a high value, the utility isn't penalized substantially for (and sometimes profits from) paying retail rates to buy wholesale energy.

- Metering requirements are fewer (needing one meter, rather than two), and accounting is simplified (again because of one meter rather than two).

- It is a great incentive to end-users to implement renewable energy technologies that have many desirable benefits but are just becoming marginally economic. 


\section{Specific System Design Issues}

\section{Differences Between Photovoltaic PCUs and Rotating Generators}

It is important to make the distinction between the mode of operation of a photovoltaic PCU and a rotating-type generator that may be interconnected with the utility grid.

A rotating generator acts as a voltage source that can generate independent of the grid, and is synchronized with it. The photovoltaic PCU, in general, acts as a sinusoidal current source that is only capable of feeding the utility line when voltage and frequency are within standard limits. This has two ramifications:

1/ The possibility of islanding, or independent operation of a section of the distribution system powered by the PCU is far less likely than with a rotating generator, as line voltage is not generally maintained by photovoltaic PCUs. (See however the following section).

2/ Under fault conditions, a rotating generator can deliver most of its spinning energy into the fault. A photovoltaic PCU, being in general a controlled-current device, will naturally limit the current into a fault to little more than normal operating current. As the photovoltaic cells themselves act as current-limited devices (as output current is proportional to sunlight), these too act to limit longer term fault currents.

An exception to the simple model of a photovoltaic PCU behaving as a simple ac current source was proposed by Cocconi et al. [1984] who pointed out that by changing the control circuits in a photovoltaic PCU, it is possible to make it act as a voltage source with a finite, lossless output impedance. This has the advantage of tending to improve utility power quality, but the disadvantage of acting more like the voltage source of a rotating generator. Fault currents are still limited though. Cocconi addressed this by designing the frequency control loop to be unstable, as discussed in the following section on islanding.

\section{System Ownership \& Point of Interconnection}

There are two possible future scenarios for ownership of PV power systems: they will either be owned, installed and maintained by the utility as part of its generating plant or, the systems will be owned and operated by private entities that are both customers and suppliers of electricity to the utility.

A key distinction from the utility and code point of view, is whether a utilityowned PV power system is covered by the National Electrical Code (the NEC - note that all references to the NEC refer to the 1993 Edition, unless otherwise noted). The specific language in the 1993 NEC governing Scope is Article 90-2-(b)-5 which reads "This code does not cover ... installations under the exclusive control of electric utilities ... for the generation ... of electric energy ... located outdoors on property owned or leased by the utility ... or outdoors by established rights on private property. ... It is the intent of this section that this Code covers all premises wiring, or wiring other than utility-owned metering equipment, on the load side of the service point of buildings, structures, or any other premises not owned or leased by the utility."

This means that even if a PV system is utility owned, for it to be exempt from the NEC, it must be connected to the utility side of the service connection point, and located on property owned or leased, or located by established rights, by the 
utility. Even under these conditions, there have been local jurisdiction questions when the system in question is mounted on the roof of a building with public access.

When a utility owns a PV system, then all of the following issues are of concern, but if the system is privately owned, then the utility need only be concerned with PCU operation, and its interconnection to the grid.

Article 690-64 of the NEC states that the point of connection from the output of the power production source shall be at either the load or the service side of the service disconnect. This is often impractical in large (especially high-rise) commercial buildings where the service may be at high voltage ( $>600$ volts) and the service disconnect is located in the basement. In such cases a code variance is required. Since code variances are often difficult or time consuming (or impossible) to get, it would be helpful to have article 690-64 changed to allow interconnection at a service panel that is electrically close to the PV system.

\section{Non-Utility-Specific Issues}

\section{PV Array Mounting and Wiring}

The PV array may be mounted on the ground, on a flat or sloping roof system or as an architectural element such as a building facade. In the northern hemisphere, for maximum annual output, the array should be mounted facing true south, with a tilt of slightly less than the latitude (say 5 degrees) angle up from horizontal. The interconnection and wiring of photovoltaic modhe service disconnect. This is often impractical in large (especially high-rise) commercial buildings where the ules is covered by Article 690 of the NEC and also by the UL draft document DOE/JPL 955392-3 (refer to Appendix A for more details).

\section{Voltage and Safety}

The 1993 NEC specifies in Article 690-7(c) that the maximum photovoltaic source circuit voltage allowable is $600 \mathrm{~V}$. Article 690-7(a) states that the rated voltage must be the open-circuit voltage of the PV array. In bipolar systems the absolute (not algebraic) sum of monopole open circuit voltages should be used to determine the system voltage and rating of components. Inverter manufacturers that have systems operating slightly over the 600-volt limit are revising their designs to operate with open circuit voltages at or below 600 volts. Bipolar systems with system voltages well above 600 volts (plus to minus voltages of 1000 to 1400 volts and more) require careful equipment selection for proper perfomance, durability and safety.

There has been some discussion about removing this 600-volt limitation from a future version of the NEC, as some studies have shown that inverter costs can be minimized by operating at higher source-circuit voltages. While higher voltages may be desirable for utility-scale and large commercial systems, the safety issues raised by high-voltage dc power systems indicate that residential and small commercial systems should operate at as low a dc source voltage as is practical and cost-effective.

\section{Ground Fault Detection and Interruption}

Article 690-5 of the NEC states that "Roof-mounted photovoltaic arrays located on dwellings shall be provided with ground-fault protection to reduce fire hazard." The detail in the NEC Handbook makes it clear that this ground-fault interrupter (GFI) is for fire, rather than personnel protection, and so needs to operate at the ampere, rather than the milliampere level. 
At present there is little practical or cost-effective equipment available to implement this function, so few roof-mounted residential systems have actually complied with this section of the code. Several manufacturers are either planning to include GFI at a reasonable cost in their inverters, or offer it as an external option.

Article 690-5 also states that the GFI circuit shall disable the array. The NEC Handbook implies that this should be done by shorting the array, but the Handbook's commentary is not a mandatory part of the code. There is some controversy at present as to whether it is better to short the array, or simply opencircuit all source conductors. Shorting the array minimizes array voltage.

\section{Inverter Siting \& Acoustic Noise}

The inverter may be mounted either indoors, in a utility room or adjacent to the distribution panel and service entrance, or especially in milder climates, on the outside of the building to facilitate installation, access and maintenance in utilityowned systems.

Presently available inverters emit considerable acoustic noise. This should be taken into account when choosing the mounting location, especially in residential applications.

\section{Grounding of the PV Array Source Circuit}

Article 690-41 of the NEC states that PV source circuits must be solidly grounded or use another scheme that accomplishes equivalent system protection. It is common practice in Europe to have the PV source circuits ungrounded. This is an area that is somewhat controversial. There are definite benefits to a solidly grounded PCU input circuit: it is far less susceptible to lightning transients if tied to earth ground. A good compromise would be to arrange for all PV array output conductors to be switched for maintenance (i.e. remove the hard grounding requirement from the NEC) but state that one of the PV output circuits should be at ground potential in normal operation.

\section{Transient Protection}

It is important to include transient protection for the PCU both on the incoming DC source circuits, and on the ac utility connection, as this equipment is especially vulnerable to high-voltage spikes and surges commonly induced by lightning activity.

\section{Electromagnetic Interference}

Present PCUs operate at $6-20 \mathrm{kHz}$ switching frequency and may generate radiofrequency signals that could interfere with radio and TV broadcasts. Ultimately, PCUs must conform to suitable standards in this area (e.g. Code of Federal Regulations 47 , Telecommunications, Part 15, as required in the personal computer industry).

\section{Utility-Specific Issues}

\section{Interconnection Voltage and Interconnect Location}

Residential and commercial inverters are available in sizes from $2 \mathrm{~kW}$ to $6 \mathrm{~kW}$ with $120-\mathrm{V}, 208-\mathrm{V}, 240-\mathrm{V}$ and $277-\mathrm{V}$ single-phase output. Larger inverters, typically above $20 \mathrm{~kW}$, are designed to feed a $480-\mathrm{V}$ three-phase supply. In commercial installations, it is presently common practice to feed three-phase power systems 
with separate single-phase inverters, as accurate phase-to-phase current balance is not required. The NEC does have some restrictions on unbalanced connections as discussed in NEC 690-63.

The actual interconnection from the inverter to the utility service is typically made by back-feeding a circuit breaker on the distribution panel. The NEC requires that any backfed circuit breaker be identified (listed) for that use and be retained by an additional securing device.

\section{Metering Methods \& Financial Arrangements with the Utility}

A major part of an interconnection agreement between the PV system owner and the utility consists of determining the financial arrangement for buying and selling power, and the necessary metering scheme to support this arrangement. The basic options are:

- For net metering, a single bi-directional meter is all that is required.

- For separate buy and sell rates, two individual ratcheted meters are required to determine the amounts of energy consumed and generated.

- More complicated schemes that take advantage of time-of-use rates are possible and may require either one or two meters capable of time-of-use recording.

\section{Manual Disconnect from the Utility}

Many utility interconnection guidelines (e.g., see the PG\&E Power Producers Interconnection Handbook) require an accessible (i.e., external to the building), lockable, safety disconnect switch with visible blades so that line crews can isolate an independent power system during maintenance operations in the area to ensure worker safety.

For residences, while these switches appear to be a prudent measure, in actuality they are seldom used, and if the distribution system is to be powered down anyway, it is little extra work to remove the supply meter instead (when the PV system is connected on the load side of the meter.) A number of utilities, including Southern California Edison and New England Electric allow meter removal as the external utility disconnect means. In some cases fire officicials may require an external disconnect and a means to short-circuit the array. Systems with batteries may also be required to have a battery disconnect.

Commercial buildings present their own problems, as suitable external locations for a disconnect may be difficult to find and, as distances from the PCU to the switch location may be considerable (or extreme in high-rise buildings), large costs can be accrued that can make the entire installation unworkable.

The long-term answer is that distributed generating sources such as photovoltaics must automatically and reliably disconnect from the line on loss of power (tests to confirm this capability are presently being planned for all currently available photovoltaic inverters at Sandia National Labs), and new standards of utility maintenance practice must be introduced to allow for both known and unknown distributed generating sources in power distribution systems. 
The National Electrical Safety Code (NESC) states in Section 173 that a visible break disconnect switch is mandatory only for circuits of more than $600 \mathrm{~V}$, and then only if lines may have to be worked on without protective grounding.

ANSI/IEEE Standard 1001-1988, The IEEE Guide for Interfacing Dispersed Storage and Generation Facilities with Electric Utility Systems, addresses this issue in its Section 9 - Safety. This article recognizes the danger of distributed generation equipment energizing isolated sections of utility line and stresses the need for testing and grounding of lines before any work commences as standard procedure.

An important issue is the possibility, due to equipment failure, of dc injection onto a utility feeder. Even with a transformer-isolated inverter, this could be possible if, for example, a PCU input circuit conductor became loose and contacted an output conductor. It is important that line crews be trained to check for dc as well as ac electricity, and appropriately ground all conductors before work commences. The NESC describes situations and methods of placing protective grounds in Sections 444 and 445.

Another problem associated with the utility requirement for the manual disconnection of distributed generators is that access must be available to the generating site at all times. In concept, this seems not to be a problem, as access is also required to the utility metering. However, the utility metering personnel are not the same people as the service personnel, and the need for service on the distribution system often comes at night and in very bad weather conditions.

In addition, as the number of distributed PV systems increases, it will become increasingly difficult for the utility service personnel to even keep track of the sheer number of systems, where they are located, the type of disconnect and its specific location.

IEEE Standard 1001 already recognizes the problems in dealing with multiple manual disconnect switches as the penetration of distributed generation devices increases, and suggests that "an acceptable automatic disconnect scheme that can meet safety guidelines may become preferable."

The installation of grounding clusters, as is standard practice for many utilities, is the only absolutely reliable way of guaranteeing a non-energized line.

\section{Insurance Issues}

Utilities may request proof of insurance coverage from customers as part of the interconnection requirements for customer-owned generation. These

requirements have often been based on the risk associated with large-scale, fossilfueled central plants, and so may be excessive. It is important to differentiate between the different types of generation systems and to specify insurance needs accordingly, as excessive insurance requirements, by themselves, are sufficient to make PV systems non-competitive on an economic basis.

Some utilities that have a number of residential-scale PV systems within their service territory have concluded that the normal liability umbrella coverage provided by the typical homeowner's policy is more than adequate. Other utilities (e.g., San Diego Gas and Electric) have required that the homeowner's liability policy have a statement that acknowledges the existence of the PV system. Homeowners might also wish to increase the insurance on their homes to cover the cost of the PV system. 


\section{Output Overcurrent Protection}

As photovoltaic PCUs contain internal current limiting circuitry, output circuit conductors are inherently protected against overcurrent from the PV system; in addition the overcurrent protection between the inverter and the grid is designed to protect the ac and dc wiring from currents from the grid during faults in the PV system wiring.

\section{Power Quality}

\section{Harmonic Content}

Many older PCUs for small wind and photovoltaic systems were of the linecommutated type, which injected essentially squarewave rather than sinusoidal current waveforms into the power distribution system. Virtually all currently available UI PCUs use pulse-width modulation (PWM) to generate high-quality sinusoidal currents, so harmonic injection should not be a problem.

Suggested limits for current distortion are specified in IEEE Standard 519-1992, IEEE Recommended Practices and Requirements for Harmonic Control in Electrical Power Systems. Table 10.3 in this document sets a worst-case harmonic total demand distortion of $5 \%$ and individual harmonics (in percent) as follows:

\begin{tabular}{|c|c|c|c|}
\hline Harmonic Number $\leq 11$ & $11-16$ & $17-23$ & $\underline{24-35}$ \\
\hline Odd Harmonics & & 1.5 & 0.6 \\
\hline Even Harmonics & 0.5 & 0.4 & 0.15 \\
\hline
\end{tabular}

Total demand distortion is defined as "the harmonic current distortion in percent of maximum demand load current (15-. or 30-minute demand)."

These limits are intended to result in a maximum line voltage total harmonic distortion of $5 \%$, and $3 \%$ for any individual harmonic.

It is important to note that voltage distortion is not under the control of the PCU (which is generally a current source), but is more a function of the impedance of the distribution line, so voltage distortion limits for a PCU while often specified, are not appropriate unless line impedance is also specified. The UL draft document on photovoltaic PCUs, Subject 1741 , specifies no more than $5 \%$ total $\mathrm{rms}$ harmonic voltage, and no more than $3 \%$ for any one harmonic into a $0.32+$ j0.14 $\Omega$ line impedance. Harmonic distortion standards should be revised to specify current distortion, since this is the parameter which a PCU designer can control.

Some commercial PCUs use an internal PWM switching frequency of around 6 $\mathrm{kHz}$, or approximately at the 100th harmonic of the utility fundamental. Distortion at the switching frequency can be considerable and can cause interference with communications equipment such as power-line carrier control systems. For example, there is recent evidence of a photovoltaic PCU inhibiting operation of a utility carrier-controlled hot water heater [Wills, 1993]. There is a need for suitable limits for these higher harmonics to be specified.

\section{Power Factor}

As with harmonic distortion, the older line-commutated inverters generated current waveforms with poor power factor, but modern PWM inverters can generate power at unity power factor (i.e., the output current is exactly in phase with the utility voltage). 
Inverter designs that generate other than unity power factor (and so can be used for power factor correction), are possible. However, these units must necessarily store energy through part of each cycle and are thus generally more expensive and less efficient than unity power factor inverters.

\section{Injection}

There are two possible approaches to designing photovoltaic PCUs which will eliminate dc injection. One uses a $60 \mathrm{~Hz}$ transformer in the output of the inverter (for example, the Abacus Controls Sunverter inverters), while the other is either transformerless, such as in Omnion's standard designs, or uses a high-frequency transformer, such as in the Pacific Inverter design.

The latter types of inverter can potentially feed asymmetrical waveforms, or even pure direct current onto the utility grid. (This is not a problem for inverters such as the Abacus, as their output transformers cannot pass direct current). This can lead to two potential problems.

One concern is that a utility service person will test an isolated line fed with dc voltage as showing zero ac voltage, leading to a hazardous situation. The presence of dc voltage on an ac distribution system is an unlikely circumstance considering that most ac loads and the distribution transformer secondaries represent very close to a short circuit for dc power. The only real risk is when the PV system is disconnected from the distribution transformer.

The second concern is that high levels of dc current might cause saturation in distribution transformers or problems (again mainly due to transformer saturation) in customer equipment. In practice, dc current injected into the distribution transformer will simply offset the operating point of the flux curve, as flux is a function of current, irrespective of its type (i.e., ac or dc) or sign. At full load, the transformer will be pushed closer to saturation on the side to which the offset has occurred. Considering the safety factor with which power distribution transformers are designed, a dc current exceeding $10 \%$ of the transformer rating would be required to cause a significant problem. In any situation in which the transformer is not dedicated to the PCU, this is unlikely to happen.

It is worthwhile noting that there are many existing loads that can generate asymmetric current waveforms, and hence offset the operating point of the distribution transformer; one example is the diode-fed incandescent "energysaving" light bulb.

As 60-Hz transformers are bulky, expensive and introduce loss, and as it is imperative that PCU prices be minimized to make photovoltaics cost effective, a mandate that inverters either contain a low-frequency transformer, or use an external isolation transformer would be detrimental to widespread

commercialization. Instead, suitable protection circuitry sensing the generation of any significant dc current component can be used.

This is recognized in the UL Draft 1741 in Section 23.1: "A PCU shall be designed to protect against direct current flowing from the PV array into the utility supply ... Devices such as an isolation transformer ... a blocking capacitor or a direct current sensor with a high speed disconnect switch may be used." 


\section{Safety Requirements}

\section{Protective Relaying}

Present PCU designs typically include the following protective relaying functions in their control circuitry:

- Under/Over Voltage (typically line voltage $\pm 10 \%$ )

- Under/Over Frequency (typically line frequency $\pm 1 \mathrm{~Hz}$ )

- DC Current Injection (if no $60 \mathrm{~Hz}$ isolation transformer is used)

Any deviation outside these limits will cause the inverter to shut down and disconnect from the utility line within a few cycles.

Some designs also monitor phase change (i.e., instantaneous frequency) and cause a shutdown if a phase change of more than 2 degrees is observed. This can lead to very rapid shutdown under islanding conditions, but can also lead to problems if the inverter is to be used with small engine-generator grids.

A recent study by the IEEE Power Systems Relaying Committee Working Group C5 (See Appendix A) has concluded that suitable circuitry within a PCU is technically capable of performing the necessary protection functions. The only issues that must be resolved are the reliability of such circuits, and the need for standardization with regard to trip settings and their testing and adjustment.

Protective functions recommended by the working group include:

- Transient overvoltage suppressors

- AC \& DC undervoltage/overvoltage trips

- Current overload and short-circuit protection

- Under-frequency and over-frequency trips

- Abnormal current flow in grounding conductor

- Loss and return of utility line voltage (reclosing)

- Over-temperature

\section{Shutdown on Under/Over Voltage/Frequency}

Shutdown when the utility supply is outside standard limits is desirable so that PCUs do not feed power into distant system faults, etc. The limits of operation are set out in IEEE 929 and UL Subject 1741 as $80 \%$ to $106 \%$ of the nominal voltage, and $+/-1 \mathrm{~Hz}$ in frequency. Some utilities specify their own operating limits in their interconnection documents. This may cause problems if the local limits differ from the ANSI/IEEE Standard, in that it is impractical to customize inverter operation for each utility. The IEEE and UL standards quoted above should become a part of a set of uniform interconnection guidelines upon which each utility can then base its own interconnection rules for small distributed systems.

\section{Shutdown on Loss of Utility}

Shutdown upon loss of utility power is generally accomplished by means of the under-voltage trip. Some PCUs initiate an instantaneous trip on line undervoltage (or any sensed trip condition); however as the penetration of distributed power generation increases, this could lead to unstable operation. A consensus is evolving that a shutdown within 20 cycles is adequate for personnel protection and would help to maintain power quality. This may require that automatic recloser operation be modified to protect against reconnection to an out-of-phase island (described below). Conversely, PCUs must be able to cope with such a situation in the unlikely event it should occur. 


\section{Islanding}

Islanding is the continuing operation of power generator(s) with an isolated section of distribution line and associated loads after the main connection to utility power is lost. This could possibly occur if a PCU is operating into an exactly matched load (with respect to real and reactive power) and the utility connection is severed.

One commonly used method of protecting against such an event is to design the inverter frequency control system so that it is unstable in the absence of utility power and, when feeding only passive loads, will tend to drop in frequency until an under-frequency trip is generated. Such a scheme was described by Cocconi [1984].

The concern over islanding is similar to the perceived need for manual disconnect switches on distributed generation systems--that a line may inadvertently be energized during maintenance, causing a danger to utility personnel. While islanding protection schemes such as unstable frequency controls appear to be reliable ways of protecting against such events, there is always a small but finite chance of an equipment or circuit malfunction, no matter what protection schemes are used (including conventional relaying). The careful following of utility maintenance procedures including testing (for both ac and dc) and grounding of lines before working on them are the only way to assure total safety.

The only safe operating practice is to assume, especially with future high penetrations of different types of distributed generation, that islanding may occur. The same argument applies to some utilities requirements for redundant protective relaying; the heavy penalty of additional cost must be weighed against the actual increase in safety that is achieved.

There has been much research oversees on islanding. As a result of the work in Japan, that coutry now has approved in general PV power converter designs that combine at least one passive technique (e.g., under/over voltage) with one active technique (e.g., unstable frequency of line impedance sensing.)

\section{Fault Conditions}

Any PV system fault current feeding a fault on the ac side of a photovoltaic system depends on current feed through the PCU. As photovoltaic PCUs are inherently current limited in their output, they are unlikely to cause problems when feeding ground faults. The dc side of the system is not a concern in utility interconnection issues, but it needs to be clear that there is potential for dangerous conditions (both to personnel and structures) during faults on the dc side.

\section{Testing Requirements}

Most utilities already have requirements for the testing of protective relay functions of interconnected customer-owned generation at system acceptance, and periodically thereafter (typically on an annual or three-yearly basis). There is a clear need for PCUs to be designed with a test capability included. This can either be that the PCU can be operated in standby or a low power mode from a standard protective relay test set (which can supply a variable voltage and frequency waveform to the unit under test), or via a special test box that can be connected to the PCU to allow the protective functions to be tested. 


\section{Future Possibilities}

There are several developments in PCU and power control technology that may impact the implementation of utility-interactive PV systems:

\section{1/ Dual Mode PCUs}

Given that a PV array can generate power even if utility power is not available, it is an attractive option to add a small battery bank to some systems and arrange for the possibility of stand-alone operation if utility power has failed. This means that either a separate inverter has to be installed for this stand-alone function, or that the utility-interactive PCU must be able to function in both modes.

A dual-mode PCU poses more safety questions than a UI-only inverter, as it is clearly capable of feeding an island indefinitely, and would only require a failure of the UI/SA mode transfer circuitry for such a problem to occur. It may be prudent to specify either redundant or external protective relaying for such systems. Dualmode PCUs will usually have the ability to charge batteries from the grid. This ability to draw power from the grid may be usable in active anti-islanding schemes.

\section{2/ Module Scale Inverters \& Communications}

There are many potential benefits to reducing the size of the PCU and incorporating it into the PV module. Among these are

- Elimination of dc wiring

- Individual module power tracking

- Minimum system size of one module reduces the high initial cost barrier to implementation

The widespread use of these sorts of devices raises many of the above points again--how can manual disconnects and regular testing be achieved in a system consisting of many distributed inverters? One solution is communications. The ability to signal each inverter that is part of the distributed power generation system, sense its operating state, and be able to control and test it will alleviate many of the concerns associated with the safety of these systems.

\section{Summary}

In the areas of safety, and especially protective relaying, further work is needed to define common operating standards that PCUs can be designed to. The level of reliability actually needed for protection in distributed power generation systems should be clarified and balanced against the costs involved in providing higher levels of redundancy.

\section{An Overview of the Design \& Installation Process}

This section outlines the typical design and installation process involved in implementing a PV power system, with the aim of showing how the utility is involved. 


\section{Preliminary System Design}

A preliminary system design is prepared by the proposer based on a system size estimate. System size is determined either by existing load or demand requirements, available solar aperture, or equipment or financial constraints. Basic equipment selection is performed to the level of choice of inverter and PV module manufacturer and PV array mounting concepts.

\section{Utility Inquiry}

The proposer or their design engineer contacts the local utility company to determine interconnection requirements, metering scheme, and possible buy and sell rates for the generated electricity. The utility may also specify legal and insurance requirements that must be met prior to system operation.

\section{Design Review}

The initial design is revised based upon utility input, and a final design is prepared. This would include PV module, mounting, inverter and ac \& dc switchgear specifications, and a one-line diagram of the electrical system.

\section{Plan Check with Utility and Electrical Inspectors}

Detailed plans are submitted, if necessary to the utility and the electrical inspection authority for review and approval. The design is then modified as necessary based on this review.

\section{Procurement \& Transportation}

Equipment is purchased and transported to the site.

\section{Installation}

The system is installed, typically by an electrical contractor, although PV module mounting and wiring may be done by a specially trained crew. Disconnects and other equipment need to be labeled according to code.

\section{Electrical Inspection}

The electrical inspector performs a site inspection of the installation.

\section{Utility Pre-Parallel Inspection}

Utility staff observe testing of protective relay functions as required, and the power-up of the system.

\section{System On-Line}

System documentation is prepared including an O\&M manual and as-built drawings.

\section{Maintenance}

Protective relays are checked for proper operation on a regular basis. A full test of all trip functions may not be required, but as a minimum, inverter shutdown on loss of utility should be verified.

Periodic maintenance of the PV array includes checking for loose wiring and fasteners, and checking energy production records for proper operation.

\section{Conclusions}

Utility-interactive power systems are proving to be reliable and trouble-free ways of generating electricity. This has been shown in many successful demonstration projects, such as New England Electric's distributed 100-kW project in Gardner, MA, which has well over 250 system-years of successful operation and has been reviewed in great detail by researchers under contract to the Electric Power Research Institute and Sandia National Laboratories. For significant market penetration to occur however, in addition to reductions in PV module and balance of system costs, several other issues need to be resolved: 
- The existing IEEE standards and draft UL standard for PCUs need to be reviewed and accepted by utilities. PCUs manufactured and tested to these standards then can be deemed technically adequate without the need for additional field testing.

- Simplified, uniform utility interconnection guidelines for small-to-medium scale PV systems need to be developed so that the interconnection process is reasonable when compared to the value of the energy produced, and equipment requirements are consistent. Simplified application forms should also be developed.

- Utility insurance requirements should also be reasonable when compared to the risk involved. Excessive insurance requirements can significantly reduce the economic viability of small PV systems.

- The issue of islanding and associated protective relaying schemes needs to be rationalized by recognizing that no protection scheme can be absolutely reliable, and especially in the case of high-penetration distributed generation, that operations \& maintenance procedures should always assume distributed systems may be feeding the grid. Theoretically, the control schemes in contemporary inverters should be adequate to protect against islanding.

- Manual, external, lockable disconnects are a common requirement in utility interconnection requirements and some standard documents. In practice, in building-mounted residential and small-commercial systems, these disconnects are very seldom used. Two points can be made: visible disconnection can also be achieved by removing the service meter (and this is a far more economical way of achieving the same result), and at high penetration, individual disconnects are simply not practical as a means of guaranteeing that a line will not be powered--it would be too easy to overlook one device and create a safety hazard. In this high-penetration future scenario, it may be necessary to use the integral shutdown logic of the PCUs (and possibly PCU communications capabilities) as the first level of safety protection, followed by more stringent O\&M procedures that test for both ac and dc power, and ground out all lines before work commences.

- Net Metering should be seriously considered for small-to-medium scale distributed PV systems. Net metering puts the utility in the position of buying energy during peak times of day at average retail prices, which may be a benefit to the utility in some cases, and will probably never be enough of a burden with small PV systems to justify two sets of meters and the accompanying accounting and billing expense.

With changes such as these implemented, we will be well prepared for the future when cost-effective grid-connected rooftop photovoltaic power generators are viewed much like an appliance--a device that can be bought at the home center or electrical supply, that can be owner installed, and can operate silently, reliably and safely, generating power whenever the sun is shining. 


\section{Appendix A - Annotated References}

There has been much thought given to the issues of utility interactive photovoltaic systems over the past 20 years, resulting in many reports, papers and standards. These can provide a valuable resource to workers in this evolving industry, both in guiding design decisions, and in resolving issues between installers, utilities and/or electrical inspectors. The following is a compilation of some of the more relevant material.

The following Table cross-references a list of key topics to the list of documents to facilitate location of relevant information: 
Topic

Definitions

Regulatory

System Design
Sub-Topic

IEEE 928

IEEE 1001

UL 1703

PV Modules

PV Array Mounting

PV Array Wiring

DC Array Voltage

Ground Fault Detection NEC \$690-5, Wiles and Interruption

UL Listing of

Components

Grounding of the PV

Array Source Circuit

Output Overcurrent

Protection

Transient Protection

Electromagnetic

Interference

Utility Issues

Point of Interconnection NEC \$690-61, NESC

System Ownership

Interconnection Voltage IEEE 1001, NESC

Metering Methods

PSCC, PG\&E,

Strong

Financial Arrangements Wenger

with Utility

Manual Disconnect

from Utility

Site Access

PG\&E, PSCC, NESC

IEEE 1001

PG\&E, PSCC

Protective

Relaying

Shutdown on Loss of Utility (Islanding)

Fault Conditions

PCU Testing

Power Quality
Harmonic Content

Power Factor

DC Injection
IEEE C5, UL 1741

SAND87-3146, SAND87-7024

IEEE C5, IEEE 1001, SAND87-3146

IEEE 1035,

UL 1741

IEEE 519,

SAND87-3146

IEEE 929, UL 1741,

SAND87-3146

IEEE 929, IEEE 1035, UL 1741 


\section{Codes, Standards and Related Documents:}

Standards are guides for suggested practice, and as such are voluntary only, while codes such as the National Electrical Code (NEC) are mandatory, if adopted by a local or state inspection authority.

The ownership, location \& point of connection of a PV system defines which codes \& standards apply. Systems connected to the customer side of the utility meter must meet NEC requirements.

Currently, work on PV-related standards is coordinated as an ongoing program of the Solar Energy Industries Association, in association with the National Renewable Energy Laboratory (NREL), Sandia National Laboratories and the Institute of Electrical and Electronics Engineers (IEEE). A major working group is the IEEE Standards Coordinating Committee 21, Photovoltaics, which for many years has developed and published standards on both utility-interactive and stand-alone PV power systems and components.

NEC - ANSI/NFPA 70-1993, "National Electrical Code," National Fire Protection Association, Quincy, MA, 1993.

The National Electrical Code is the main document that defines the equipment, wiring and techniques that should be used in PV power systems. The most relevant section is Article 690 "Solar Photovoltaic Systems," but many other sections, such as Article 240, "Overcurrent Protection" and Article 250 "Grounding" are also applicable. The National Electrical Code is published every three years, with the latest edition being 1993, although many State and Local Authorities have not yet adopted the 1993 code, and are still operating under the 1990 version.

NEC Handbook - "National Electrical Code Handbook," National Fire Protection Association, Quincy, MA, 1993.

The NFPA publishes a handbook as a companion to the NEC. This book contains the full text of the NEC as well as additional explanation, drawings and diagrams that clarify many points made in the code. While the additional text provided in the Handbook is not part of the code, it is a useful guide to interpretation, and for understanding the intent of the NEC itself.

NESC - ANSI/NFPA C2-1993, "National Electrical Safety Code," National Fire Protection Association, Quincy, MA, 1993.

The NESC is the National code applying to utilities and industrial establishments. It has been adopted by 48 states and the majority of public service commissions nationwide. It provides safety guidelines for conductors and equipment in situations where a PV generating system is utility owned, and located on property leased or owned by the utility. It may also apply to any large commercial system that is not connected to the load side of a utility service meter. 
Wiles, John C., "Photovoltaic Power Systems and the National Electrical Code: Suggested Practices," Southwest Technology Development Institute, New Mexico State University PO Box 30001/Dept. 3SOL, Las Cruces, New Mexico 88003-0001.

John Wiles' Recommended Practices is an invaluable supplement to the NEC that brings forth PV systems issues and relates them to the code. Issues covered are PV modules, wiring and conductor ampacity, groundfault protection, grounding, overcurrent protection, disconnecting means, panel-boards and enclosures, batteries, generators, charge controllers, distribution systems, and labels and warnings. A list of suppliers of specialized PV equipment is included.

\section{IEEE/ANSI Standards:}

There are three types of IEEE Standard: Standards (which are binding), Recommended Practices (which detail "preferred" practices), and Guides (which are suggested approaches to "Good Practice").

IEEE STD 519-1992, "IEEE Recommended Practices and Requirements for Harmonic Control in Electrical Power Systems," IEEE Industry Applications Society/Power Engineering Society, April 1993.

This recently revised standard is a comprehensive document that addresses all aspects of harmonic generation and their effects on electric loads. The sections of specific interest to UI PV systems are:

4.4 - Harmonic Generation by Inverters for Dispersed Generation. This section makes the point in particular that the utility may "have undesirable effects on the output of the inverter. Variables such as ambient utility harmonics, unbalanced line voltages, unequal phase separation, high and low levels of AC voltage, and line impedances are several variables that affect the output harmonics of the inverters."

6.10 - Effects of Harmonics on Static Power Converters. This section again points out that ambient utility harmonics can cause problems, either by causing excessive heating in capacitor filter circuits, or by interfering with normal inverter operation (especially in terms of logic interference and zero crossing detection) to the extent that serious damage might be caused.

Sections 8 (Analysis Methods), 9 (Measurements) and 10-12

(Recommended Practices) could be useful in particular cases. One of the design goals of current PCUs using high-frequency switching is to reduce harmonic currents to an acceptable level.

Section 10.4 and Table 10.3 define the recommended maximum harmonic distortion limits for generating equipment.

ANSI/IEEE STD 928-1986, "IEEE Recommended Criteria for Terrestrial Photovoltaic Power Systems," IEEE Standards Committee 21, Photovoltaics, May 1986.

This standard establishes general performance criteria for terrestrial PV power systems. Its intent is to provide an overall framework for detailed performance standards. It also discusses sub-system performance and test methods. 
This standard contains a number of useful definitions, such as for StandAlone Systems, Residential, Intermediate and Central Station UI Systems. The remainder of the standard is in the form of a general outline that lists a complete set of possible performance requirements, e.g., such things as voltage, current and power factor definitions, environmental impact etc., and testing, installation, operation and maintenance requirements.

ANSI/IEEE STD 929-1988, "IEEE Recommended Practice for Utility Interface of Residential and Intermediate Photovoltaic (PV) Systems," IEEE Standards Coordinating Committee 21, Photovoltaics, May 1987.

This standard addresses the basic issues of power quality, equipment protection and safety in UI photovoltaic power systems in a brief but concise manner. In power quality, it states limits for service voltage range and discusses flicker, frequency, and harmonic generation.

On equipment protection and safety, it covers the need to protect against islanding, and to disconnect when utility voltage goes outside of specified voltage and frequency limits for more than two seconds (i.e., the singlephase voltage as specified in ANSI C84.1-1982 of $86.7 \%$ to $105.8 \%$ of nominal operating voltage, and frequency outside 59.0 to $61.0 \mathrm{~Hz}$ ). It also states that reconnection to the line should not.occur until the supply has been within limits for a suitable time, typically 30 to 120 seconds.

In addition, IEEE 929 states that PCUs should not inject dc current into the ac interface, under "normal or abnormal conditions," that grounding and surge protection should be performed according to applicable codes and that a lockable and accessible manual load-break disconnect switch should be provided.

ANSI/IEEE STD 1001-1988, "IEEE Guide for Interfacing Dispersed Storage and Generation Facilities with Electric Utility Systems," IEEE Standards Coordinating Committee 23, Dispersed Storage and Generation, April 1989.

This is a valuable and wide-ranging document covering all of the issues regarding dispersed storage and generation (DSG). Many sections in this document may be of use to those involved in PV system design or installation:

Section 1: Regulatory Requirements - discusses applicable regulations, including the Public Utility Regulatory Policies Act (PURPA), which mandates that electric utilities must purchase electric energy and capacity made available by qualifying cogenerators and small power producers.

Section 2 gives an overview of typical electric distribution systems, including issues such as circuit protection and automatic reclosing.

Section 3 discusses dispersed storage and generation technologies, including photovoltaic generators (Section 3.3.2) and dc to ac converters (PCUs).

Section 4 lists other standards that may be applicable to dispersed generation systems (most of which are listed in this appendix), as well 
as listing technical considerations for generating systems and associated power conversion units.

Section 5 covers utility concerns and requirements, all of which stem from complications involved in paralleling the generating system with the utility. These are: personnel safety, power quality, islanding, circuit protection, and effects on utility planning and operations.

Section 6 covers potential day-to-day and minute-to-minute operations problems associated with DSG, including operating reserve, automatic generation control, peaking units, load forecasting, unit commitment, system security analysis, power pooling and system control.

Section 7 covers protection of the DSG/Utility interface. It states that four principles should be considered for protection: dependability, security, selectivity, and speed. It covers such specific areas as selection and placement of current and voltage transformers, selection of protective devices and transfer tripping.

Section 8 discusses communications for DSG systems, including (possible) necessity, functions, basic technical requirements, equipment and communications media. It concludes that communications for DSG systems may be necessary, but because of the multiple factors involved, it may be a complex undertaking.

Section 9 covers safety, both on the utility side of the interconnection (discussing present utility safety practices, including the testing and grounding of transmission and distribution systems, and recommended new maintenance procedures, the need for more sectionalizing switches and directories of DSG sites, and the need for either a manual disconnect switch, or automatic disconnect capability for a high penetration of DSG systems (\$ 9.2.4)) and the DSG side of the interface (allowing for overcurrrent protection, loss of utility, issues of grounding, ground fault protection and O\&M procedures).

Section 10 is a comprehensive bibliography divided into the following sections: DSG, windpower, solar energy systems, cogeneration, protection, inverters \& storage, guides, regulatory \& economic considerations, hydro-electric generation, induction generators, miscellaneous technologies and personnel safety.

All of the sections in IEEE 1001 have useful lists of references that could aid further investigation.

ANSI/IEEE STD. 1035-1989, "IEEE Recommended Practice: Test Procedure for Utility-Interconnected Static Power Converters," IEEE Standards Committee on Dispersed Storage and Generation (SCC 23), November 1989.

This standard lists a recommended practice for testing utilityinterconnected static power converters (i.e., PCUs). The areas covered are power factor and harmonic measurement, voltage and frequency trips, time for SPC disconnect, and conducted and radiated EMI detection. It is important to note that these tests are written at the level of factory or testing laboratory certification, and so, while being a useful guide for field tests, requires a significant amount of time and test equipment that may not 
be justifiable on the average installation. IEEE 1035 also contains a useful bibliography on inverter testing.

\section{IEEE Stationary Battery Standards:}

This collection contains several standards that relate to battery storage in photovoltaic systems, and as such are most relevant to stand-alone systems. As it is likely that in future we will see dual-mode (UI \& S/A) inverters with storage for standby and peak-shaving use, these standards are listed as a useful reference. The IEEE Stationary Battery Standards Collection contains amongst others:

ANSI/IEEE STD 937-1987, "Recommended Practice for Installation and Maintenance of Lead-Acid Batteries for Photovoltaic (PV) Systems."

ANSI/IEEE STD 1013-1990, "Recommended Practice for Sizing Lead-Acid Batteries for Photovoltaic (PV) Systems."

ANSI/IEEE STD 1145-1990, "Recommended Practice for Installation and Maintenance of Nickel-Cadmium Batteries for Photovoltaic (PV) Systems."

\section{UL Standards:}

DOE/JPL 955392-3, "Safety Requirements for Wiring Systems and Connectors for Photovoltaic Systems," Underwriters Laboratories Inc., Illinois, September 1984.

This document was prepared by Underwriters Laboratories for the Jet Propulsion Laboratory in the form of a report, but is also considered by UL to be a draft standard. It addresses the requirements for photovoltaic wiring systems, and first examines a large number of NEC wiring systems (Article 320 - Open wiring on Insulators - through Article 363 - Flat Cable Assemblies), then reduces this to six candidate systems (NM/NMC, SE/USE, UF, TC, FCC and "photovoltaic cable"). In addition, various wiring termination methods are investigated. This report suffers from being rather dated - for example, the 1993 NEC now allows types USE and UF single conductor PV interconnections.

UL Subject 1741, "Draft Standard for Power Conditioning Units for use in Residential Photovoltaic Power Systems," Underwriters Laboratories Inc., September 1982.

This draft UL standard was prepared by UL as a report to MIT Lincoln Laboratory in 1982, and now forms the basis of the proposed UL standard for UI photovoltaic PCUs. It differs from IEEE 1035 above in that it is more concerned about electrical safety to personnel and the risk of fire than with electrical performance.

Issues covered are construction (such things as sheet metal thickness and opening sizes, accessibility to live parts etc., mounting, corrosion protection, mechanical assembly, switches and controls, field wiring connections, wiring terminals, bonding for grounding, input circuit grounding, internal wiring, live parts, separation of circuits, spacings, insulating materials, capacitors, fuses and fuseholders, dc isolation from the utility, motors, printed wiring boards, critical components), protection against injury to persons (enclosures and guards, mounting, materials, moving parts, impact, stability, switches and controls, utility fluctuation, static load \& surface 
temperatures), performance (output voltage, temperature, dielectric voltage withstand, harmonic distortion, utility fluctuations (including islanding), environmental conditions, voltage transient \& static discharge, abnormal operation, terminal torque, grounding impedance \& rating), marking (content, cautionary markings, information and instructions) and manufacturing and production tests (dielectric voltage withstand, critical controls check \& burn-in). This is a very comprehensive document that contains much information from similar equipment standards, and so is quite detailed and complete.

ANSI/UL 1703-1987, "Standard for Flat-Plate Photovoltaic Modules and Panels," American National Standard, March 1987.

This is the UL standard to which three manufacturers now have product listing: Siemens Solar, Solarex and Tideland Signal. UL 1703 is currently undergoing an ANSI standard review process.

The areas covered in this standard are Introduction (scope, glossary, etc.)

Construction (materials, wiring, connectors, fire resistance)

Performance (temperature, voltage, current \& power, leakage current $\&$ dielectric voltage withstand, strain relief test, various mechanical tests)

Production Line Tests (dielectric voltage withstand, voltage, current \& Rating \& Marking power, grounding continuity)

\section{Other Standards:}

Federal Communications Commission, Rules and Regulations, Radio Frequency Devices, Part 15, Subpart J, 1981.

These rules may govern the radio frequency emission limits from PCUs and other equipment.

\section{Reports:}

Stiez and Associates, "Photovoltaic Power Conditioning: Status and Needs," EPRI GS-7230 Project 1996-20, Sandia National Laboratories and Electric Power Research Institute, June 1991.

This report was the result of a joint effort between Sandia National Laboratories and the Electric Power Research Institute. It describes the current status, and future needs in PCU development, but specifically addresses large, utility scale inverter systems. Areas covered are

Past field experience System Level Issues (DC interface, $\mathrm{AC}$ interface) Power Conditioning Technology \& Cost Trends Applications Synergies \& Vendor Viewpoints Market Outlook Key Findings

EPRI EL-6754 - New England Power Service Company, "Photovoltaic Generation Effects on Distribution Feeders, Vol. 1," Electric Power Research Institute, March 1990. 
This report is a description of the Gardner, MA 21st century PV community and research program. The system consists of 30 grid-connected roofmounted residential PV power systems, each $2 \mathrm{~kW}$ nominal. It was designed and installed by Solar Design Associates for New England Electric in 1986 and monitored and modeled by Worcester Polytechnic Institute and Ascension Technology. All houses are in one neighborhood, on the very end of one phase of a $13.8-\mathrm{kV}$ feeder. This high saturation of inverters is a preview of what may become commonplace in the next century.

The research was in four areas: steady state and slow transients, fast transients, harmonics, and overall performance of the distribution system.

The basic conclusions were that well designed PCUs result in very small amounts of harmonic voltage and current distortion, even when operated in clusters and high levels of penetration. In fact, the harmonic generation of 150 Watt personal computer power supplies and fluorescent lamps was found to be more significant than that of 2000-watt high-quality PCUs.

Regarding slow transients (e.g., changing cloud cover), it was found that conventional feeder designs and voltage regulation techniques can deal adequately with the cloud-induced variations in PV generation.

Regarding fast transients, the PCUs did not create problems with either the utility or customers during feeder faults, induced lightning surges, capacitor switching, and large load changes, and did not run on more than $8 \mathrm{~ms}$ after a feeder was dropped.

There was no detectable electrical interaction between the many PCUs on the feeder.

Hassan, M. and J. Klein, Distributed Photovoltaic Systems: Utility Interface Issues and Their Present Status, DOE/ET-20356-3, Jet Propulsion Laboratory, California, September 1981.

This report shows the level of detail that was achieved 12 years ago in this area. At that time, very few standards or guidelines existed, but the writers (and the DOE at the time) saw the need for ensuring a smooth integration of dispersed power systems into the utility system. In terms of standards and understanding, we have come a long way.

The main areas of the report are

Protection ("Some guidelines for protection requirements for DSG have been formulated by various utilities. These requirements ... may not be entirely applicable to a multiplicity of sources.")

Stability (Needs Study)

System Unbalance (Needs Study)

Voltage regulation and reactive power requirements (There was no standard definition of power factor under non-sinusoidal conditions - this was remedied by IEEE 519). 
Harmonics (A limit of 5\% total voltage distortion was proposed - little work had been done in this area in the USA at the time)

Safety (Modifications to the NEC were suggested to address PV \& PCU grounding, isolation transformers may, or may not be needed (some things don't change) and manual disconnects were seen as a universal requirement that "may be impractical when there is a large penetration of PV sources." Islanding was also an issue).

Metering (Metering requirements will be defined by rate structures - utilities are not worried about harmonic effects on meter operation).

Utility operations (Operations will not be affected until large penetrations are achieved, then possible rapid power fluctuations could cause problems).

Distribution system planning \& design. (Future studies are planned).

Das, R., J. Klein, T. W. Macie, Distributed Photovoltaic Systems: Utility Interface Issues and Their Present Status, JPL-PUBL-82-63, Jet Propulsion Laboratory, California, September 1982.

This second volume discusses utility interface issues for intermediate/three phase systems. The main issues that were identified were PCU protection, voltage regulation, safety and code requirements, metering, harmonics and resonance effects, utility overcurrent protection, stability, system planning, and system operations.

SAND87-3146 - Stevens, John, The Interconnection Issues of Utility-Intertied Photovoltaic Systems, Sandia National Laboratories, Albuquerque, July 1992.

This report is a summary of many years of valuable research performed at Sandia National Laboratories on PCU interface characteristics. It gives some background to the PCU testing program, describes various types of PCUs, and then discusses the issues of harmonic generation, power factor, flicker, and utility system dynamics (disconnect on fault/islanding). A useful list of references is also presented.

The islanding issue is interesting, as while most manufacturers consider this issue to be resolved, the report states "All self-commutated PCSs tested would recognize a utility disconnect and respond properly when load watts or vars are more than $20 \%$ different than PV watts or vars. However, when the load is carefully selected for the PCS output, most units could be made to run on, in some cases, indefinitely." It is surprising that this issue has not yet been resolved as it appears to be technically straightforward to make the PCU frequency control loop unstable when feeding any passive load, and this should solve the problem. A new set of tests is being planned on the current generation of PCU to see if contemporary control algorithms also have run-on problems.

SAND87-7024 - Robert A. Jones and Thomas R. Sims, Investigation of Potential Islanding of dispersed Photovoltaic Systems, Sandia National Laboratories, Albuquerque, October, 1988. 
This report is an in-depth study of the islanding potential of three inverters, all unfortunately now not in production - units by Gemini, Teslaco, and APCC. The research was designed to determine the conditions of load and generation at which run-on could occur. The procedure was to perform computer simulations that were later verified with laboratory and field tests. On the whole, this is a very complete and complex work that concluded that a suitably designed control system, such as the Teslaco's, could totally eliminate the possibility of indefinite run-on for all levels of load and generation.

EPRI GS7227, "Experiences and Lessons Learned with Residential Photovoltaic Systems," Miles Russell \& Edward Kern, Electric Power Research Institute, 1991, reprinted in Solar Today, May/June 1992.

This report analyzes three UI residential PV projects, examining utility benefits (peak demand reduction), rooftop placement of PV arrays, public and homeowners reactions, customer ownership drawbacks, barriers to customer investment in PV, benefits of utility ownership, interface issues and monitoring. It makes the interesting argument that utility ownership has significant benefits, such as assured quality and performance, economies of scale, and the availability of trained service personnel.

IEEE-C5, "Static Power Converters of $500 \mathrm{~kW}$ or Less Serving as Relay Interface Package for Non-Conventional Generators." IEEE Power System Relaying Committee, Working Group C5.

The control circuits that are an integral part of PCU systems must necessarily monitor the status of utility power for proper operation. As such, they can perform double duty in also performing the required protective relaying functions. Working group $\mathrm{C}-5$ is preparing a report that concludes that the control inherent in static inverters can indeed be adequate to meet utility protective relaying requirements. They state that the PCU should protect itself against damage as a result of abnormal conditions at the ac or dc interfaces (including utility faults), the PCU should shutdown upon internal failure or loss of utility, and be protected against surges and over-temperature.

\section{Papers:}

Shugar, Dan, "Distributed PV Benefits for Utilities." PG\&E research group. Presented at Distributed Photovoltaic Power - Electric Utility Experience and Opportunities, Gardner, MA 1991.

This paper from the PG\&E research group examines the financial benefits that photovoltaics can give to a utility system in terms of transmission and distribution system support at times of peak load.

Wenger, H., Hoff \& Perez, "Photovoltaics as a Demand Side Management Option: Benefits of a Utility-Customer Partnership," World Energy Engineering Congress, Atlanta, GA 1992.

This paper, also from the PG\&E research group, explores the possibility of utility rebates for customer owned PV systems. The utility gains $T \& D$ and bulk power benefits (while losing some revenue), but the customer loses in having to pay for the capital and operating costs of the system (while gaining lower utility bills and tax benefits). The concept is that a rebate 
paid from utility to the customer, set at slightly less than the utility's net gain, can change the balance on the customer side and make the system economically attractive.

\section{Other References:}

Blackburn, Lewis, J., "Protective Relaying - Principles and Applications," Marcel Dekker, NY 1987.

This is one of the major texts on utility protective relaying and is a useful resource for protective relaying concepts and terminology.

PG\&E, "Power Producer's Interconnection Handbook," Pacific Gas and Electric . Company, California, June 1992.

This is an example of a complete specification for utility interconnection. It is a well presented and thought-out document that is required reading for any interconnection to PG\&E, be it $2 \mathrm{~kW}$ or $2 \mathrm{MW}$. Unfortunately, the hundreds of pages of information are relevant to large-scale generation as well as residential scale PV. The need for a standard, brief set of interconnection guidelines designed specifically for PV systems is clear.

Contents include: general provisions, metering, protective relaying, manual disconnects, reactive and voltage requirements, parallel inspection, operating procedures, a glossary, and a number of appendices.

PSCC - Safety, Interference and Interconnection Guidelines for Cogeneration, Small Power Producers and Customer-Owned Generators," Public Service Company of Colorado, August, 1991.

Another example of a utility interconnection document, containing sections on the PSCC system, system integrity, general design requirements, specific relaying requirements, metering requirements, testing and operating requirements. While less thick that the PG\&E document, it still covers systems to $10 \mathrm{MW}$ and over.

PSCC is one of the minority of utilities that at this point require redundant protective relaying in addition to the inherent protection in PV power conditioning units.

Strong, Steven J., "The Solar Electric House," Sustainability Press, Still River, MA 01467-0143, 1991.

First published in 1987, this reference book is one of the few texts that addresses utility interactive (as well as stand-alone) PV power systems. The chapter on UI systems includes a description of UI photovoltaic system configurations and components, sizing UI arrays and three case studies.

SAND87-7023 - Daystar Inc., Stand-alone Photovoltaic Systems: A Handbook of Recommended Design Practices, Sandia National Laboratories, Albuquerque, November 1991.

Although this handbook is written specifically for non-utility intertied PV systems, it provides valuable insight into the design process for PV systems, 
including discussions of solar resource, array sizing, energy efficient loads and life-cycle economics. 


\section{Appendix B - List of Contact People \& Resources}

\section{Sandia PV Design Assistance Center}

Hal Post, Division 6218

Sandia National Laboratories

Albuquerque, NM USA 87185

Phone (505) 844-2154, Fax (505) 844-6541

\section{IEEE}

Institute of Electrical and Electronics Engineers

345 East 47th St.

New York, NY 10017

Phone (800) 678-4333 publications

or (212) 705-7900 for general inquiries

\section{NFPA}

National Fire Protection Association

1 Batterymarch Park

PO Box 9101

Quincy, MA 02269-9904

Phone (800) 344-3555

\section{ANSI}

American National Standards Institute

1430 Broadway, New York, NY 10018

UL

James Feth

Underwriters Laboratories, Inc.

333 Pfingsten Road

Northbrook, IL 60062-2096

Phone (708) 272-8800

\section{SEIA}

David Meakin

Solar Energy Industries Association

122 C Street, N.W.

4th Floor

Washington, DC 20001-2109

Phone (202) 383-2617, Fax (202) 383-2670

(Coordinator, PV Systems Standards)

\section{EPRI}

Ed DeMeo

Electric Power Research Institute

3412 Hillview Avenue

Palo Alto, CA 94303

Phone (415) 855-2797, Fax (415) 855-2954

\section{John Wiles}

Southwest Technology Development Institute

Box 30001/Dept. 3SOL

Las Cruces,

New Mexico 88003-0001 Phone (505) 646-6105, Fax (505) 646-3841 
$3 \mathrm{~T}$

Mr. Terry Kunimuni, President

650 North Brand Blvd. - Suite 1940

Glendale, CA 91203

3M Company

Mr. Paul Jaster, 223-4W-14

3M Center

St. Paul, MN 55144-1000

Abacus Controls, Inc.

Mr. George O'Sullivan, President

80 Readington Road

PO Box 893

Somerville, NJ 08876

Advanced Photovoltaic Systems, Inc.

Daniel Shugar

150 Tehama Court

San Bruno, CA 94066

AeroVironment Inc.

Dr. Paul B. MacCready, President \& CEO

825 Myrtle Avenue

Monrovia, CA 91016

Alaska Energy Authority

Mr. Brent Petrie, Dir. of Agency Ops.

701 E. Tudor Road

PO Box 190869

Anchorage, AK 99519-0869

All Star Electric Co.

Mr. Mike LaVine,

11708 Candelaria NE, \#A

Albuquerque, NM 87112

Alpha Solarco, Inc.

Mr. Ed Schmidt,

11534 Gondola Drive

Cincinnati, OH 45241

American Solar Energy Society

Mr. Donald Aitken, Chairman

20100 Skyline Blvd.

Woodside, CA 94062
Ananda Power Technologies, Inc.

Mr. Bob Cobler, 14618 Tyler Foote Road

Nevada City, CA 95959

Apollo Energy Systems

Mr. Wayne Best,

200 Louise Street, PO Box 238

Navasota, TX 77868-0238

Applied Power Systems

Mr. Timothy Ball,

1210 Homann Drive SE

PO Box 7122

Lacey, WA 98503

Arizona Public Service - Star Facility

Mr. Peter E. Eckert, Sr. C\&I Engineer

PO Box 53999 MS4160

Phoenix, AZ 85072-3999

Arizona Energy Office

Mr. Mark Ginsberg,

3800 North Central, Suite 1200

Phoenix, AZ 85012

Arizona Electric Power Cooperative

Mr. James Rein, Manager of Engineering

PO Box 670

Benson, AZ 85602

Arizona State University

Mr. Robert L. Hammond,

PO Box 875806

Tempe, AZ 85287

Arizona State University

Dr. Chuck Backus,

College of Engineering

Tempe, AZ 85287

Arizona State University

Professor Emeritus Paul Russell, Prof. Emeritus

5902 East Caballo Lane

Scottsdale, AZ 85253 
Arthur D. Little, Inc.

Ms. Lisa Frantzis, Senior Consultant Acorn Park

Cambridge, MA 02140-2390

Ascension Technology

Dr. Edward C. Kern, Jr., President PO Box 314

Lincoln Center, MA 01773

Ascension Technology

Mr. Miles Russell,

PO Box 314

Lincoln Center, MA 01773

\section{ASRC}

Mr. Richard Perez,

100 Fuller Road

Albany, NY 12205

\section{AstroPower, Inc.}

Mr. James Beck, Sr. Design Engineer Solar Park

Newark, DE 19716-2000

AstroPower, Inc.

Mr. Allen M. Barnett, President

30 Lovett Avenue

Newark, DE 19711

AWS Scientific, Inc.

Mr. Bruce Bailey,

3 Washington Square

Albany, NY 12205

Bechtel National, Inc.

Mr. Walt Stolte,

PO Box 193965

San Francisco, CA 94119-3965

Blue Mountain Energy

Ms. Kay Firor,

59943 Comstock Road

Cove, OR 97824

Bluepoint Associates

Mr. Art Dickerson, President

245 Hacienda Ave.

San Luis Obispo, CA 93401
Bonneville Power Administration

Mr. Minje Ghim,

PO Box 3621, RPED

Portland, OR 97208

Carrizo Solar Corp.

Mr. Michael S. Elliston,

1320 12th St NW

Albuquerque, NM 87104

Central \& Southwest Services, Inc.

Mr. Ed Gastineau, Director of Research

PO Box 660164

Dallas, TX 75266-1336

City of Wisconsin Rapids

Mr. Raymond W. Weber, Chairman, CMP3

City Hall Building

444 West Grand Avenue

Wisconsin Rapids, WI 54494

City of Austin Electric Utility

Mr. Kenneth Ragsdale, Alt. Energy Eng. Town Lake Center, 721 Barton Springs Rd. PO Box 1088

Austin, TX 78704

City of Austin Electric Utility

Mr. John Hoffner, Prog. Mgr, Altn. Energy

Town Lake Center, 721 Barton Springs Rd.

PO Box 1088

Austin, TX 78704

Consolidated Edison Co of NY, Inc.

Mr. Ralph J. Mauro, Senior Research Engineer

4 Irving Place

New York, NY 10003

Coors Brewing Co.

Mr. Larry Dugan, Senior Engineer

CE200

Golden, CO 80401

Coors Brewing Co.

Mr. Roger Thompson, Principle Electrical Engineer CE200

Golden, CO 80401 
Currin Corporation

Mr. Ed Currin,

PO Box 1191

Midland, MI 48641-1191

Daystar

Mr. Vern Risser, President

1034 Roadrunner Court

Las Cruces, NM 88001

Delmarva Power \& Light

Mr. Ralph Nigro, Design Eng. ME Dept.

PO Box 6066

Newark, DE 19714-6066

Detroit Edison Co.

Mr. Robert Pratt,

2000 2nd. Avenue

Detroit, MI 48226

Detroit Edison Co.

Mr. Norm Stevens

2000 2nd. Avenue

Detroit, MI 48226

\section{Dynamote}

Mr. Brian Faley,

1200 West Nickerson

Seattle, WA 98119

Electric Power Research Institute

Dr. Frank Goodman, Proj. Mgr, Solar Sys.

3412 Hillview Ave.

PO Box 10412

Palo Alto, CA 94303

Electrotek Concepts, Inc.

Mr. Bob Zavadil,

480 San Antonio Road, Suite 200

Mountain View, CA 94040

Electrotek

Mr. Charles Smith,

10305 Dutchtown Rd., Suite 103

Knoxville, TN 37932
Electrotek Concepts, Inc.

Mr. Greg Ball,

480 San Antonio Road, Suite 200

Mountain View, CA 94040

Endecon

Mr. Chuck Whitaker,

3401 Crow Canyon Road - Suite 253

San Ramon, CA 94583

ETA Engineering, Inc.

Mr. Lane Garrett, President

8502 Cactus Wren Road

Scottsdale, AZ 85250-4907

Florida Power Corp.

Ms. Christy Herig,

3201 34th Street South, MS H2M

St. Petersburg, FL 33711

Florida Power and Light

Mr. R. S. Allen,

PO Box 14000

Juno Beach, FL 33408

Florida Power Corporation

Mr. Antonio A. Padilla, Manager, New Technology 3201 34th Street South, MAC A4D

St. Petersburg, FL 33733

Florida Solar Energy Center

Mr. Jim Dunlop,

300 State Road 401

Cape Canaveral, FL 32920

Florida Solar Energy Center

Dr. Gerard G. Ventre, Solar Programs Director

300 State Road 401

Cape Canayeral, FL 32920

Florida Solar Energy Center

Library ,

300 State Road 401

Cape Canaveral, FL 32920

General Electric Industrial \& Power Sys.

Dr. Ali F. Imece, Power Systems Engineering Dept. One River Road

Schenectady, NY 12345 
Georgia Power Company

Ross Kist

PO Box 4545

Atlanta, GA 30302

Hawaii Electric Light Co., Inc.

Mr. Clyde H. Nagata,

PO Box 1027

Hilo, HI 96816

Hawaii Electric Light Co., Inc.

Mr. Alva K. Nakamura, Mgr. of Eng.

54 Halekauila Street

Po Box 1027

Hilo, HI 96721-1027

Heart Interface Corporation

Michael Hirata

21440 68th Avenue South

Kent, WA 98032-2416

Helionetics, DECC Division

Dr. Larry Suelzle,

17312 Eastman St.

Irvine, CA 92714

Home Power Magazine

Mr. Richard Perez,

PO Box 130

Hornbrook, CA 96044-0130

Idaho Power

Mr. John Prescott,

PO Box 70

Boise, ID 83703

Integrated Power Corporation

Dave Panico

7524 Standish Place

Rockville, MD 20855

Integrated Power Corporation

Mr. Ted Blumenstock, Vice Pres. Business

Development

7524 Standish Place

Rockville, MD 20855
InterIsland Solar

Mr. Will Hartzell,

345 N Nimitz Highway

Honolulu, HI 96817

Kenetech

Bill Erdman

6952 Preston Ave

Livermore, CA 94550

Knutson Engineering

Mr. Kurt A. Knutson, Owner

3709 Goldsby St. SW

Olympia, WA 98512

La Plata Electric Assoc., Inc.

Mr. Mark Schwantes, Chief Engineer

PO Drawer H, 45 Stewart St.

Durango, CO 81302

Laf Young Associates

Mr. Lafayette Young, President

Star Route One, Box 42

Haiku Maui, HI 96708

Maui Electric Co. Ltd.

Mr. Neal K. Shinyama, Elec. Staff Engr.

210 Kamehameha Avenue

PO Box 398

Kahului, Maui, HI 96732-0398

Meridian

Mr. James F. Hoelscher, Senior Technical Manager

4300 King Street, Suite 400

Alexandria, VA 22302-1508

Michigan State University

College of Engineering

Dr. Gerald L. Park, Prof of EE \& Sys

East Lansing, MI 48824

Mobil Solar Energy Corporation

Paul Wormser

4 Suburban Park Drive

Billerica, MA 01821-3980 
Morningstar Corporation

Dr. Kenneth Gerken, President

3414 Morningwood Drive, Suite 200B

Olney, MD 20832

Mr. Steve Chalmers,

4044 East Whitton

Phoenix, AZ 85018

National Renewable Energy Laboratories Lynn Coles

1617 Cole Boulevard

Golden, CO 80401-3393

National Renewable Energy Laboratories Mr. Dick Deblasio, 1617 Cole Boulevard

Golden, CO 80401-3393

National Renewable Energy Laboratories

Mr. Roger Taylor, 1617 Cole Boulevard

Golden, CO 80401-3393

National Renewable Energy Laboratories Mr. Carl Osterwald, 1617 Cole Boulevard

Golden, CO 80401-3393

National Renewable Energy Laboratories John Thornton

1617 Cole Boulevard

Golden, CO 80401-3393

Naval Weapons Center

Mr. Garyl Smith,

Naval Weapons Center Code 02A1

China Lake, CA 93555-6001

NEOS Corporation

Mr. Cary Lane, PV Engineer

165 South Union Blvd.; Suite 260

Lakewood, CO 80228

NEOS Corporation

Mr. Kirk Stokes,

165 S. Union, Suite 260

Lakewood, CO 80228
New York Power Authority

Mr. Mark Kapner

1633 Broadway

New York, NY 10019

New England Power Service Co.

Mr. John Bzura,

25 Research Drive

Westborough, MA 01582

Niagara Mohawk Power Corp.

Mr. Clayton Burns, Program Manager, R\&D A-2

300 Erie Blvd. West

Syracuse, NY 13202

North Carolina Solar Center

Mr. Bill Brooks,

North Caroling State University

PO Box 7401

Raleigh, NC 27695-7401

Northern Power Systems

Mr. George Barlowe,

1 North Wind Road

Moretown, VT 05660

Omnion Power Electronics, Inc.

Mr. Dave Porter,

2010 Energy Drive

PO Box 879

East Troy, WI 53120

Omnion Power Engineering

Mr. Hans Meyer

2010 Energy Drive

PO Box 879

East Troy, WI 53120

Orion Energy Corporation

Mr. Doug Danley, President

18131 Metz Drive

Germantown, MD 20874

Outside Power Consultants

Mr. Bradley E. O'Mara, President

7477 Lakeshore Drive

Spirit Lake, IA 51360 
Pacific International Center For High Technology Research Mr. Richard E. Rocheleau, Project Engineer 2875 S. King Street, 1st Floor

Honolulu, HI 96826

Pacific Energy Group

32 Valla Court

Walnut Creek, CA 94596

Pacific Inverter, Inc. Mr. David Ross, President

509 Granite View Lane

Spring Valley, CA 92077

Pacific Gas \& Electric

Brian Farmer, Project Manager PVUSA

3400 Crow Canyon Road

San Ramon, CA 94583

Philadelphia Electric Co.

Mr. Donald A. Fagnan, Supervising Engineer-

Research \& Planning

2301 Market Street (S10-1)

Philadelphia, PA 19101

Photocomm, Inc.

Mr. Joel Oatman, 7681 East Gray Road

Scottsdale, AZ 85260

Photocomm

Kevin Conlin

13130 Stafford Rd.

Stafford, TX 77477

Photocomm, Inc.

Mr. Walter O'Neill, 7681 East Gray Road

Scottsdale, AZ 85260

Photron Inc.

Mr. Lawrence Jennings, 77 West Commercial Street PO Box 578

Willits, CA 95490
PICTR

Mr. Warren Bollmeier,

711 Kapiolani Blvd., Suite 200

Honolulu, HI 96813 -5249

PICTR

Mr. Andy Trenka, Director

711 Kapiolani Blvd., Suite 200

Honolulu, HI 96813 -5249

Power Electronics Application Center

Mr. Tom Key,

10521 Research Drive, Suite 400

Knoxville, TN 37932

Public Service Co. Colorado

Mr. Ron Fish,

550 15th Street, Room 420

Denver, CO 80202

Public Service Company of New Mexico

Mr. Dennis Hines, Engineer

Alvarado Square

Albuquerque, NM 87158

Public Service Co. of Colorado

Chris Thompson

2701 W. 7th Ave.

Cenver, CO 80204

Puerto Rico Office of Energy

Mr. Lewis Smith,

PO Box 41089, Minillas Station

San Juan, PR 00940

PV Insider's Report

Mr. Richard Curry,

1011 West Colorado Blvd.

Dallas, TX 75208

PV Resources International

Mr. Bill Kaszeta, President 1440 West Meseto Ave.

Meas, AZ 85202

PV Energy Systems

Mr. Paul Maycock, President

Rt 2 Box 429

Catlett, VA 22019 
Quality Power Engineering

Mr. Ed M. Gulachenski, President

8 MacNeill Drive

Southborough, MA 01772

Real Goods Trading Co.

Mr. John Shaeffer,

966 Mazzoni Street

Ukiah, CA 95482

Remote Power Inc.

Mr. Len Loomans,

1608 Riverside Ave.

Fort Collins, CO 80524

Sacramento Municipal Utility District

Mr. Don E. Osborn,

6507 4th Ave., Suite 400

Sacramento, CA 95817-1899

Sacramento Municiple Utility District Mr. Dave Collier, 6291 S Street

Sacramento, CA 95852-1830

Salt River Project

Mr. G. E. Ernie Palomino, Consulting Engineer,

$\mathrm{R} \& \mathrm{D}$

PO Box 52025

Phoenix, AZ 85072-2025

San Diego Gas \& Electric

Mr. Al Firueroa,

PO Box 1831

San Diego, CA 92112

Sandia National Laboratories

Mr. Dan Alpert

2140 L Street NW, \#709

Washington, DC 20037

Sandia National Laboratories

Mr. Thomas Bickel, MS 0752

PO Box 5800

Albuquerque, NM 87185
Sandia National Laboratories

Mr. Richard N. Chapman, MS 0753

PO Box 5800

Albuquerque, NM 87185

Sandia National Laboratories

Mr. Abbas Akhil, MS 0613

PO Box 5800

Albuquerque, NM 87185

Sandia National Laboratories

Mr. Ward I. Bower, MS 0753

PO Box 5800

Albuquerque, NM 87185

Sandia National Laboratories

Mr. Jack Cannon, MS 0753

PO Box 5800

Albuquerque, NM 87185

Sandia National Laboratories Mr. Roger R. Hill, MS 0753

PO Box 5800

Albuquerque, NM 87185

Sandia National Laboratories

Mr. Christopher Cameron, MS 0753

PO Box 5800

Albuquerque, NM 87185

Sandia National Laboratories

Dr. Paul Butler, MS 0613

PO Box 5800

Albuquerque, NM 87185

Sandia National Laboratories

Mr. Garth Corey, MS 0613

PO Box 5800

Albuquerque, NM 87185

Sandia National Laboratories

Dr. Paul Klimas, MS 0704

PO Box 5800

Albuquerque, NM 87185

Sandia National Laboratories

Mr. Dan E. Arvizu, MS 0735

PO Box 5800

Albuquerque, NM 87185 
Sandia National Laboratories Mr. Jim Freese, MS 0613 PO Box 5800

Albuquerque, NM 87185

Sandia National Laboratories Mr. M. Max Harcourt, MS 0753 PO Box 5800

Albuquerque, NM 87185

Sandia National Laboratories Mr. Jerry W. Ginn, MS 0753 PO Box 5800

Albuquerque, NM 87185

Sandia National Laboratories Mr. Ron C. Pate, MS 0753

PO Box 5800

Albuquerque, NM 87185

Sandia National Laboratories Mr. Russ H. Bonn, MS 0753 PO Box 5800

Albuquerque, NM 87185

Sandia National Laboratories Mrs. Marjorie L. Whipple, MS 0752 PO Box 5800

Albuquerque, NM 87185

Sandia National Laboratories Mr. John W. Stevens, MS 0753 PO Box 5800

Albuquerque, NM 87185

Sandia National Laboratories Mr. Mike G. Thomas, MS 0753

PO Box 5800

Albuquerque, NM 87185

Sandia National Laboratories Mr. Hal N. Post, MS 0753

PO Box 5800

Albuquerque, NM 87185
Sandia National Laboratories Ms. Elizabeth H. Richards, MS 0753 PO Box 5800

Albuquerque, NM 87185

Scientific Analysis, Inc.

Mr. J. Allen Gunn, 6012 East Shirley Lane

Montgomery, AL 36117

Siemens Solar Industries

Dr. Raju Yenamandra, 4650 Adohr Lane

PO Box 6032

Camarillo, CA 93010

Siemens Solar Industries

Mr. Larry Shushner, Manager

4650 Adohr Lane

PO Box 6032

Camarillo, CA 93011

Skyline Engineering (50)

Dr. Robert Wills, PE

Applewood Lane

Route 45, Box 134

Temple, NH 03084-0134

Solar Design Associates, Inc. (50) Mr. Steven Strong, President

PO Box 242

Harvard, MA 01451-0242

Solar Electric Specialties Co.

Mr. Mike Ashmore, Sales Engineer PO Box 537

Willits, CA 95490

Solar Technology Institute

Mr. Ken Olson,

PO Box 1115

Carbondale, CO 81623

Solar Energy Industries Association Keith Duran 777 North Capitol St. NE - Suite 805 Washington, DC 20402-4226 
Solar Energy Industries Association

Mr. David H. Meakin, Standards Coordinator

777 North Capitol Street, NE

Suite 805

Washington, DC 20002-4226

Solarelectric Co. of New Mexico

Mr. Steve Verchinski, President

2700 Espanola NE

Albuquerque, NM 87110

Southern Company Services

Jeff Burleson

64 Perimeter Center East, Bin 231

Atlanta, GA 30346-6401

Southern California Edison

Lawrence Pace

PO Box 800

Rosemead, CA 91770

Southern Company Services

Mr. D. Lane Garrett,

PO Box 2525

Birmingham, AL 35202

Southern California Edison

Mr. Paul Skvarna,

$6090 \mathrm{~N}$ Irwindale Ave.

Irwindale, CA 91720

Southwest Technology Development Institute Mr. Steven Durand, Manager

1505 Payne St.

PO Box 3SOL

Las Cruces, NM 88003

Southwest Technology Development Institute

Mr. John Wiles Jr.,

1505 Payne St.

PO Box 30001 Dept.3SOLAR

Las Cruces, NM 88003

Stephen Hester

2497 Morello Heights Circle

Martinez, CA 94553
Sun Electric (Sunelco)

Mr. Dan Brandborg, Owner/Manager

100 Skeels

PO Box 1499

Hamilton, MT 59840

SunAmp Power Co.

Mr. Steve Bass, Marketing Director

1902 Country Club Dr. Suite 8

Mesa, AZ 85201

Sunnyside Solar

Ms. Carol Levin,

Road 4, Box 808

W. Brattleboro, VT 05301

Texas Instruments, Inc.

Mr. Eric Graf, PV Marketing Manager

13532 N. Central Exwy.

PO Box 655936 MS35

Dallas, TX 75265

Texas Instruments, Inc.

Dan Mosher

13532 N. Central Expressway

PO Box 65012 MSS35

Dallas, TX 75243

Trace Engineering

Mr. Steve M. Johnston, Vice President,Engineering

5917 195th NE

Arlington, WA 98223

Trace Engineering

Mr. Greg Thomas, Electrical Designer

5917 195th NE

Arlington, WA 98223

Tucson Electric Power Co.

David Eubank,

P.O. Box 711

Tucson, AZ 85702

U.S. Department of Energy

Mr. Jim Rannels,

Forrestal Building, MS CE352

1000 Independence Avenue SW

Washington, DC 20585 
U.S. Department of Energy

Mr. Alec Bulawka,

Forrestal Building, MS CE352

1000 Independence Avenue SW

Washington, DC 20585

U.S. Department of Energy

Mr. Michael W. Pulscak, PV Energy Technology

Forrestal Building, MS CE352

1000 Independence Avenue SW

U.S. Department of Energy

Mr. Robert H. Annan, Director .

Forrestal Building, MS CE-13

1000 Independence Avenue SW

Washington, DC 20585

Underwriters Laboratories, Inc.

Mr. Paul Duks, Senior Engineer

333 Pfingsten Road

Northbrook, IL 60062-2096

Underwriters Laboratory

Mr. Tom Lundtviet, Sr. Staff Engineer, EE Dept.

333 Pfingsten Road

Northbrook, IL 60062

\section{United Solar Systems}

Mr. Larry Slominski,

5278 Eastgate Mall

San Diego, CA 92121-2814

United Solar Systems Corp.

Mr. Dick Blieden,

1100 W. Maple

Troy, MI 48084

University of Lowell

Dr. Ziyad Salameh, Dept of EE

1 University Avenue

Lowell, MA 01854

University of Texas at Arlington

Mr. Jack Fitzer,

West 6th at Speer St.

Arlington, TX 76019
University of South Florida

Mr. Tom Smith, Eng. 118-RMENB379

4202 E. Fowler Ave.

Tampa, FL 33620

Utah Energy Office

Mr. Britt Reed,

3 Triad Center, Suite 450

Salt Lake City, UT 84180-1204

Utility Photovoltaic Group

Mr. Mike Bergman,

1800 M ST NW, Suite 300

Washington, DC 20036

Utility Power Group

Mr. Mike Stern, President

9410-G DeSoto Avenue, Unit G

Chatsworth, CA 91311

Utility Power Group

Mr. Rick West,

4444 Orcutt Road

San Louis Obispo, CA 93401

Utility Photovoltaic Group

Bob Mauro

1800 M ST NW, Suite 300

Washington, DC 20036

Vanner, Inc.

Mr. Jay Bowling, National Sales Manager

4282 Reynolds $\mathrm{Dr}$.

Willard, $\mathrm{OH} 43026$

Virgin Islands Energy Office

Mr. Shabbar Saifee,

81 Castle Coakley

Christiansted, VI 00820

Western Area Power Administration

Mr. Stephen L. Sargent, Renewable Energy

Engineer

1627 Cole Boulevard, A7100

Golden, CO 80401 
Westinghouse Electric Corp.

Mr. David K. Goeser, Mgr, Solar Energy Operations

PO Box 355

Pittsburg, PA 15230

Westinghouse Electric Corp.

Mr. Art Lilley, Mgr., Solar Energy Ops

PO Box 355

Pittsburg, PA 15230

Zomeworks Corporation

Mr. Steve Baer, President

PO Box 25805

Albuquerque, NM 87125

Sandia Distribution

$\begin{array}{ll}0702 & \text { D.E. Arvizu, 6200 } \\ 0702 & \text { A. VanArsdall, 6200 } \\ 1127 & \text { M.E. Ralph, 6215 } \\ 0753 & \text { C.P. Cameron, 6218 } \\ 0753 & \text { T.L. Baca, 6218 } \\ 0753 & \text { R.H. Bonn, 6218 } \\ 0753 & \text { W.I. Bower, 6218 } \\ 0753 & \text { J.E. Cannon, 6218 } \\ 0753 & \text { S.R. Harrington, 6218 } \\ 0753 & \text { R.R. Hill, 6218 } \\ 0753 & \text { T.D. Hund, 6218 } \\ 0753 & \text { W. Lewis, 6218 } \\ 0753 & \text { R.C. Pate, 6218 } \\ 0753 & \text { H.N. Post, 6218 } \\ 0753 & \text { J.W. Stevens, 6218 (50) } \\ 0753 & \text { M.G. Thomas, 6218 } \\ 0752 & \text { M.L. Tatro, 6219 } \\ 0899 & \text { Technical Library, 7141 (5) } \\ 0619 & \text { Technical Publications, 7151 } \\ 0100 & \text { Document Processing for DOE/OSTI, } \\ & \text { 7613-2 (10) } \\ 9018 & \text { Central Technical Files, 8523-2 }\end{array}$

